Received: 24 Maret 2021

Revised: 17 Juni 2021

Accepted: 23 Juni 2021

Published: 30 Juni 2021

\title{
Analisis Klaster untuk Pengelompokkan Kabupaten/Kota di Provinsi Maluku Berdasarkan Indikator Pendidikan dengan Menggunakan Metode Ward
}

\author{
Dewi L.S ${ }^{1, \text { a) }}$, M. W. Talakua ${ }^{1, b)}$, Y. A. Lesnussa ${ }^{1, c)}$, M. Y. Matdoan ${ }^{1, d)}$ \\ ${ }^{1}$ Program Studi Matematika, Fakultas Matematika dan Ilmu Pengetahuan Alam, Universitas Pattimura, \\ Jl Ir. Putuhena, Ambon, Provinsi Maluku, 9723. \\ E-mail: a)ewhy130699@gmail.com, b) ocat_talakua@yahoo.com, ${ }^{c}$ yopi_a_lesnussa@yahoo.com, \\ d)keepyahya@gmail.com
}

\begin{abstract}
Cluster analysis is a method of analysis that aims to cluster objects based on their similar characteristics. The method used in cluster analysis is the hierarchical method. In general, the hierarchical method is divided into 5, namely: single linkage, complete linkage, average linkage, Ward and centroid with a measure of the euclidean distance. The purpose of this research is to find out the results of clustering of districts / cities in Maluku Province based on educational indicators using the Ward method. The results of the research on clustering of districts / cities were 3 clusters, the first cluster consisted of 2 districts / cities, namely Central Maluku and Ambon City with the high level of education. The second cluster consists of 4 districts namely West Seram Regency, Buru Regency, East Seram Regency and Tanimbar Islands Regency with low education levels, the third cluster consists of 4 districts / cities, namely Southeast Maluku Regency, Southwest Maluku Regency, Aru Islands Regency, South Buru Regency and Tual City with moderate level of education.
\end{abstract}

Keywords: Euclidean Distance, Ward Method.

\begin{abstract}
Abstrak
Analisis klaster merupakan salah satu metode analisis yang bertujuan untuk mengklasterkan objek-objek berdasarkan kemiripan karakteristik yang dimilikinya. Metode yang digunakan pada analisis klaster yaitu metode hierarki. Secara umum metode hierarki dibagi menjadi 5 yaitu : single linkage, complete linkage, average linkage, Ward dan centroid dengan ukuran jarak euclidean. Tujuan dari penelitian ini untuk mengetahui hasil pengklasteran kabupaten/kota di Provinsi Maluku berdasarkan Indikator Pendidikan dengan menggunakan metode Ward. Hasil penelitian pengklasteran kabupaten/kota sebanyak 3 klaster, klaster pertama terdiri dari 2 kabupaten/kota yaitu Maluku Tengah dan Kota Ambon dengan tingkat pendidikan yang tinggi. Klaster kedua terdiri dari 4 kabupaten yaitu Kabupaten Seram Bagian Barat, Kabupaten Buru, Kabupaten Seram Bagian Timur dan Kabupaten Kepulauan Tanimbar dengan tingkat pendidikan rendah. Klaster ketiga terdiri dari 4 kabupaten/kota yaitu Kabupaten Maluku Tenggara,
\end{abstract}


Kabupaten Maluku Barat Daya, Kabupaten Kepulauan Aru, Kabupaten Buru Selatan dan Kota Tual dengan tingkat pendidikan sedang.

Kata-kata kunci: Jarak Euclidean, Metode Ward.

\section{PENDAHULUAN}

Pentingnya pendidikan untuk kemajuan suatu wilayah dalam pembangunan yang telah disebutkan dalam Undang-Undang No. 20 Tahun 2003, bahwa pendidikan adalah mengembangkan kemampuan dan membentuk watak serta peradaban bangsa yang bermartabat untuk mewujudkan suasana belajar dan proses pembelajaran agar peserta didik secara aktif mengembangkan potensi dirinya untuk memiliki kekuatan spiritual keagamaan, pengendalian diri, kepribadian, kecerdasan, akhlak mulia, serta keterampilan yang diperlukan dirinya, masyarakat, bangsa dan negara (Selfianti \& Wardarita, 2021).

Analisis klaster sering kali dijumpai di kehidupan sehari-hari, baik yang ada dalam bidang sosial, bidang kesehatan, bidang marketing, maupun bidang pertanian. Analisis klaster yaitu suatu teknik yang dapat digunakan untuk mengklasterkan kasus ke dalam klaster yang homogen sehingga objek yang berada dalam satu klaster akan memiliki kesamaan dibandingkan dengan objek yang ada di klaster lain (Aprilia, 2016) (Oktarina,2014) (Rahmawati, 2012). Secara umum terdapat dua metode pengklasteran data dalam analisis klaster yaitu metode hierarki dan metode non-hierarki. Analisis klaster hierarki memiliki beberapa metode yaitu Single Linkage, Complete Linkage, Average Linkage, Ward dan Centroid dengan menggunakan ukuran jarak Eulidean (Laomen et al, 2019) (Sumertajaya \& Erfiani, 2007).

Penelitian sebelumnya pernah dilakukan oleh (Aprilia A.P et al., 2016) menggunakan metode Single Linkage, Complete Linkage, Average Linkage dan Ward, dan menggunakan jarak Euclidean dan pearson berdasarkan nilai Cluster Tightness Measure (CTM) yang terkecil. Penelitian lain juga dilakukan oleh (Sela Oktavia, 2013) menggunakan Metode Ward. Dari penelitian ini diperoleh 5 klaster dari pengelompokan 15 dosen jurusan Matematika FMIPA Universitas Tanjung pura yang mengajar pada semester ganjil 2011/2012.

Berdasarkan uraian diatas pada penelitian ini akan mengklasterkan kabupaten atau kota di Provinsi Maluku berdasarkan indikator pendidikan dengan menggunakan metode ward untuk melihat sejauh mana pemerataan pendidikan atau karekteristik tingkat pendidikan kabupaten atau kota di Provinsi Maluku.

\section{METODOLOGI}

\section{Data}

Data yang digunakan dalam penelitian ini adalah data sekunder yang diperoleh dari Kementrian Pendidikan dan Kebudayaan (Kemdikbud) pada tahun 2020. Dalam penelitian ini variabel penelitian dikelompokan berdasarkan banyak siswa dan banyak guru untuk setiap jenjang SD, SMP dan SMA, seperti pada Tabel 1, berikut:

TABEL 1. Variabel Penelitian

\begin{tabular}{cl}
\hline Variabel & \multicolumn{1}{c}{ Keterangan } \\
\hline $\mathbf{X}_{\mathbf{1}}$ & Banyak siswa SD \\
$\mathbf{X}_{\mathbf{2}}$ & Banyak siswa SMP \\
$\mathbf{X}_{\mathbf{3}}$ & Banyak siswa SMA/SMK \\
$\mathbf{X}_{\mathbf{4}}$ & Banyak guru SD \\
$\mathbf{X}_{\mathbf{5}}$ & Banyak guru SMP \\
$\mathbf{X}_{\mathbf{6}}$ & Banyak guru SMA/SMK \\
\hline
\end{tabular}




\section{Metode Penelitian}

Pada penelitian ini digunakan analisis klaster hierarki dengan metode Ward. Adapun prosedur yang dilakukan dalam penilitian ini yaitu :

1. Melakukan statistik deskriptif

2. Melakukan pengujian asumsi analisis klaster

a. Sampel harus mewakili populasi

Pengujian ini dilakukan dengan menggunakan nilai Kaiser-Mayer-Olkin (KMO).

b. Multikolinearitas

Untuk mengetahui apakah ada atau tidaknya multikolinearitas pada data dilakukan dengan menghitung korelasi pearson.

3. Melakukan analisis klaster dengan metode Ward.

4. Menentukan banyaknya klaster.

5. Melakukan interpretasi analisis klaster dengan menggunakan metode Ward.

\section{HASIL DAN PEMBAHASAN}

\section{Data}

Adapun data penelitian dikelompokan berdasarkan kabupaten/kota di Provinsi Maluku yang digunakan dalam proses pengklasteran, dapat dilihat pada Tabel 2. dibawah ini:

TABEL 2. Data Penelitian

\begin{tabular}{lrrrrrr}
\hline \multirow{2}{*}{ KABUPATEN/KOTA $(\mathbf{N})$} & \multicolumn{7}{c}{ Variabel Penelitian } \\
\cline { 2 - 7 } & \multicolumn{1}{c}{ X1 } & \multicolumn{1}{c}{ X2 } & X3 & X4 & X5 & X6 \\
\hline Maluku Tengah & 36984 & 28679 & 19177 & 3734 & 1764 & 1857 \\
Ambon & 34269 & 17099 & 20419 & 2285 & 1228 & 1838 \\
Seram Bagian Barat & 18991 & 10319 & 10159 & 1977 & 1013 & 1062 \\
Maluku Tenggara & 7679 & 5016 & 5364 & 701 & 833 & 527 \\
Maluku Barat Daya & 9542 & 4414 & 4265 & 835 & 570 & 391 \\
Buru & 15568 & 6359 & 6662 & 1316 & 583 & 526 \\
Seram Bagian Timur & 16460 & 5770 & 5375 & 1256 & 606 & 426 \\
Kepulauan Tanimbar & 11831 & 7374 & 6368 & 866 & 560 & 601 \\
Kepulauan Aru & 9164 & 4367 & 4590 & 822 & 459 & 363 \\
Buru Selatan & 7697 & 3733 & 3207 & 706 & 492 & 345 \\
Tual & 6904 & 3962 & 4582 & 485 & 405 & 275 \\
\hline
\end{tabular}

\section{Statistik Deskriptif}

Untuk melakukan proses pengklasteran untuk variabel $\mathrm{X}_{1}=$ Banyak siswa $\mathrm{SD}, \mathrm{X}_{2}=$ Banyak siswa SMP, $\mathrm{X}_{3}=$ Banyak siswa SMA/SMK, $\mathrm{X}_{4}=$ Banyak guru SD, $\mathrm{X}_{5}=$ Banyak guru SMP, $\mathrm{X}_{6}=$ Banyak guru SMA/SMK, terlebih dahulu dianalisis secara deskriptif.

Statistika deskriptif Indikator Pendidikan Kabupaten/Kota di Provinsi Maluku dapat dilihat pada TABEL 3. 
TABEL 3. Statistik Deskripsi Indikator Pendidikan

\begin{tabular}{cccc}
\hline & $\mathbf{N}$ & Minimum & Maksimum \\
\hline X1 & 11 & 6904 & 36984 \\
X2 & 11 & 3733 & 28679 \\
X3 & 11 & 3207 & 20419 \\
X4 & 11 & 485 & 3734 \\
X5 & 11 & 405 & 1764 \\
X6 & 11 & 275 & 1857 \\
\hline
\end{tabular}

Berdasarkan Tabel 3, dapat dilihat bahwa variabel $X_{1}$ memperoleh nilai minimum sebesar 6904, sedangkan nilai maksimum sebesar 36984. Selanjutnya $X_{2}$ memperoleh memperoleh nilai minimum sebesar 3733, sedangkan nilai maksimum sebesar 28679. Selanjutnya $X_{3}$ memperoleh memperoleh nilai minimum sebesar 3207, sedangkan nilai maksimum sebesar 20419. Selanjutnya $X_{4}$ memperoleh memperoleh nilai minimum sebesar 485 , sedangkan nilai maksimum sebesar 3734 . Selanjutnya $X_{5}$ memperoleh mqemperoleh nilai minimum sebesar 405, sedangkan nilai maksimum sebesar 1764 . Selanjutnya $\mathrm{X}_{6}$ memperoleh memperoleh nilai minimum sebesar 275 , sedangkan nilai maksimum sebesar 1857.

\section{Asumsi Analisis Klaster}

Terdapat dua asumsi yang harus dipenuhi dalam analisis klaster yaitu sampel mewakili populasi dan tidak terjadi multikolinearitas. Untuk mengetahui apakah sampel yang diambil benar-benar dapat mewakili populasi yang ada dibutuhkan nilai Kaiser-Meyer Olkin (KMO) dan untuk mendeteksi ada atau tidaknya multikolinearitas dengan menghitung korelasi pearson (korelasi sederhana).

\section{Sampel Yang Mewakili}

Hasil dari pengujian asumsi dengan Kaiser-Mayer-Olkin (KMO) sebagai berikut

TABEL 4. Uji KMO and Bartlett's Test

\begin{tabular}{ccc}
\hline Kaiser-Meyer-Olkin Measure of Sampling Adequacy & 0,778 \\
\hline Bartlett's Test of & Approx. Chi-Square & 117.422 \\
Sphericity & $\mathrm{df}$ & 15 \\
\cline { 2 - 3 } & $\mathrm{Sig}$. & $<0,001$ \\
\hline
\end{tabular}

Berdasarkan TABEL 4 KMO dan Bartlett's Test di atas terlihat nilai Kaiser-Meyer-Olkin Measure of Sampling Adequacy yaitu 0,778. Dimana nilai KMO lebih dari 0,5 maka dapat disimpulkan bahwa sampel dapat mewakili populasi dan variabel-variabel dapat dipakai untuk dianalisis lebih lanjut.

\section{Multikolinearitas}

Untuk mendeteksi ada atau tidaknya multikolinearitas dengan menggunakan nilai koefisien korelasi pearson. Keeratan hubungan antara variabel pada korelasi pearson jika nilai koefisien 0,0-0,1 tingkat hubungannya sangat rendah, 0,2-0,4 tingkat hubungannya rendah, 0,4-0,6 tingkat hubungannya cukup, 0,6-0,8 tingkat hubungannya kuat, 0,8-1 tingkat hubungannya sangat kuat (Bertan, 2016). 
TABEL 5. Correlations

\begin{tabular}{|c|c|c|c|c|c|c|c|}
\hline & & X1 & $\mathrm{X} 2$ & X3 & $\mathrm{X4}$ & $\mathrm{X5}$ & X6 \\
\hline \multirow{3}{*}{ X1 } & $\begin{array}{l}\text { Pearson } \\
\text { Corelation }\end{array}$ & 1 & 0,936 & 0,969 & 0,949 & 0,902 & 0,962 \\
\hline & Sig & & $<0,001$ & $<0,001$ & $<0,001$ & $<0,001$ & $<0,001$ \\
\hline & $N$ & 11 & 11 & 11 & 11 & 11 & 11 \\
\hline \multirow{3}{*}{$\mathrm{X} 2$} & $\begin{array}{l}\text { Pearson } \\
\text { Corelation }\end{array}$ & 0,936 & 1 & 0,922 & 0,970 & 0,959 & 0,935 \\
\hline & Sig & $<0,001$ & $<0,001$ & $<0,001$ & $<0,001$ & $<0,001$ & $<0,001$ \\
\hline & $N$ & 11 & 11 & 11 & 11 & 11 & 11 \\
\hline
\end{tabular}

Dari hasil analisis output SPSS dapat dilihat bahwa untuk $X_{1}$ dan $X_{2}$ memiliki nilai sig 0,000<0,5 maka $X_{1}$ dengan $X_{2}$ memiliki hubungan yang signifikan. Sedangkan untuk $r$ hitung $(0,963)>r$ tabel $(0,602)$ sehingga $X_{1}$ dengan $X_{2}$ memiliki hubungan yang sangat kuat dan berpola positif artinya semakin banyak siswa maka semakin banyaknya guru.

\section{Pengukuran Jarak}

Dalam menghitung tiap objek (kabupaten/kota) dihitung dengan menggunakan perhitungan jarak euclidean (Goreti et al, 2016), (Silvi, 2018), dengan rumus sebagai berikut:

$$
d_{i j}=\sqrt{\sum_{k=1}^{p}\left(x_{i k}-x_{j k}\right)^{2}}
$$

Keterangan :

$$
\begin{aligned}
& d_{i j}=\text { jarak antara objek ke-i dan objek ke- } j \\
& p=\text { jumlah variabel klaster } \\
& x_{i k}=\text { data dari subjek ke- } i \text { pada variabel ke- } k \\
& x_{j k}=\text { data dari subjek ke- } j \text { pada variabel ke- } k \\
& k=1,2, \ldots, p
\end{aligned}
$$

Berikut adalah contoh perhitungan menggunakan rumus jarak euclidean. Misalkan dihitung kemiripan antara Kabupaten Maluku Tengah dan Kota Ambon (objek 1 dan objek 2).

$$
\begin{aligned}
d_{i j} & =\sqrt{\sum_{k=1}^{p}\left(x_{i k}-x_{j k}\right)^{2}} \\
& =\sqrt{\sum_{k=1}^{6}(36984-34269)^{2}+(28679-17099)^{2}+\cdots+(1857+1838)} \\
& =\sqrt{145397447} \\
& =12058.08637
\end{aligned}
$$

Untuk perhitungan kemiripan antara Kabupaten Maluku Tengah dan Kabupaten Seram Bagian Barat (objek 1 dan objek 3).

$$
\begin{aligned}
d_{12} & =\sqrt{\sum_{k=1}^{6}\left(x_{i k}-x_{j k}\right)^{2}} \\
& =\sqrt{\sum_{k=1}^{6}(36984-18991)^{2}+(28679-10319)^{2}+\cdots+(1857+1062)} \\
& =\sqrt{746445048} \\
& =27321.14654
\end{aligned}
$$


Dari contoh tersebut dapat dilihat hasil perhitungan jarak Euclidean antara Kabupaten Maluku Tengah dengan Kota Ambon adalah 12058.08637. Sedangkan jarak Euclidean antara Kabupaten Maluku Tengah dengan Kabupaten Seram Bagian Barat adalah 27321.14654. Hal ini menunjukkan Kabupaten Maluku Tengah bahwa memiliki karakteristik yang lebih mirip dengan Kota Ambon dari pada Maluku Tengah dengan Kabupaten Seram Bagian Barat. Demikian dengan penafsiran objek yang lainnya, semakin kecil jarak antara kedua objek maka akan semakin mirip karakteristik dari kedua objek tersebut.

\section{Analisis Klaster Dengan Metode Ward.}

Analisis klaster dengan metode Ward merupakan metode yang berusaha untuk meminimalkan variasi antar objek yang ada dalam satu klaster. Kemudian data diolah menggunakan SPSS untuk mendapatkan output agglomeration schedule pada TABEL 6 dan penjelasan setiap tahapannya adalah sebagai berikut:

TABEL 6. Agglomeration schedule

\begin{tabular}{ccccccc}
\hline \multirow{2}{*}{ Stage } & \multicolumn{2}{c}{ Cluster Combined } & \multirow{2}{*}{ coefficients } & \multicolumn{2}{c}{ Stage Cluster First Appears } & Next Stage \\
\cline { 2 - 3 } & 5 & 9 & Cluster 2 & & Cluster 2 & \\
2 & 4 & 11 & 1065.667 & 0 & 0 & 5 \\
3 & 6 & 7 & 1904,279 & 0 & 0 & 4 \\
4 & 4 & 10 & 3022.060 & 2 & 0 & 6 \\
5 & 4 & 5 & 4800.959 & 4 & 0 & 5 \\
6 & 6 & 8 & 7497,225 & 3 & 1 & 9 \\
7 & 3 & 6 & 12170,812 & 0 & 0 & 7 \\
8 & 1 & 2 & 18199.855 & 0 & 6 & 9 \\
9 & 3 & 4 & 31627.009 & 7 & 0 & 10 \\
10 & 1 & 3 & 76533.702 & 8 & 5 & 10 \\
\hline
\end{tabular}

1. Berdasarkan output agglomeration schedule pada lampiran 2 pada kolom stage 1, terbentuk satu klaster yang beranggotakan Kabupaten Maluku Barat Daya (nomor urut 5) dan Kabupaten Kepulauan Aru (nomor urut 9) dengan nilai koefisien 256.901. Karena proses aglomerasi dimulai dari objek yang terdekat, maka nilai koefisien tersebut menunjukkan jarak yang terdekat dari 11 sekian banyak kombinasi objek yang ada. Selanjutnya pada kolom berikutnya (next stage) adalah stage 5. Hal ini berarti objek selanjutnya yang akan tergabung dengan objek (nomor urut 5) dan (nomor urut 9) adalah stage 5.

2. Pada stage 5 terbentuk satu klaster yaitu Kabupaten Maluku Tenggara (nomor urut 4) dan Kabupaten Maluku Barat Daya (nomor urut 5) dengan nilai koefisien 1065.667. Dengan demikian, telah terbentuk klaster terdiri dari dua objek yaitu Kabupaten Maluku Barat Daya dan Kabupaten Kepulauan Aru.

3. Pada stage 9 terbentuk klaster antara Kabupaten Seram Bagian Barat (nomor urut 3) dan Kabupaten Maluku Tenggara (nomor urut 4) dengan nilai koefisien 31627.009 yang menunjukkan besar jarak terdekat antara Kabupaten Maluku Tenggara dengan kedua objek klaster sebelumnya (Kabupaten Maluku Barat Daya dan Kabupaten Kepulauan Aru). Hal ini berarti objek selanjutnya yang akan tergabung dengan objek (nomor urut 3) dan (nomor urut 4) adalah stage 10

4. Pada stage 10 terbentuk klaster antara Kabupaten Maluku Tengah (nomor urut 1) dan Kabupaten Seram Bagian Barat (nomor urut 3) dengan nilai koefisien 76533.702 yang menunjukkan besar jarak 
terdekat antara Kabupaten Seram Bagian Barat dengan tiga objek klaster sebelumnya. Kemudian pada kolom (next stage) terlihat angka 0 yang berarti proses klastering berhenti. Kemudian proses selanjutnya dilakukan pada tahap belum diproses sampai proses klaster berhenti.

\section{Menentukan Banyak Klaster}

Dalam menentukan anggota klaster peneliti memilih untuk pengklasteran objek-objek dalam 3 klaster dapat dilihat pada Tabel 7. Dari output cluster membership tersebut dapat dilihat anggota dari masing-masing klaster sebagai berikut :

TABEL 7. Anggota dari Klaster yang Terbentuk

\begin{tabular}{cc}
\hline KLASTER & \multicolumn{1}{c}{ KABUPATEN/KOTA } \\
\hline Klaster 1 & Kabupaten Maluku Tengah, Kota Ambon. \\
Klaster 2 & $\begin{array}{l}\text { Kabupaten Seram Bagian Barat, Kabupaten Buru, Kabupaten } \\
\text { Seram Bagian Timur, Kabupaten Kepulauan Tanimbar. }\end{array}$ \\
Klaster 3 & $\begin{array}{l}\text { Kabupaten Maluku Tenggara, Kabupaten Maluku Barat Daya, } \\
\text { Kabupaten Kepulauan Aru, Kabupaten Buru Selatan, Kota Tual }\end{array}$ \\
\hline
\end{tabular}

\section{Interpretasi Analisis Klaster}

Setelah klaster terbentuk maka tahap selanjutnya adalah memberi ciri spesifik untuk menggambarkan isi klaster tersebut berdasarkan kemiripan/karakteristik antar objek yang diteliti. maka diperoleh interpretasi klaster dapat dilihat pada Gambar 1, sebagai berikut:

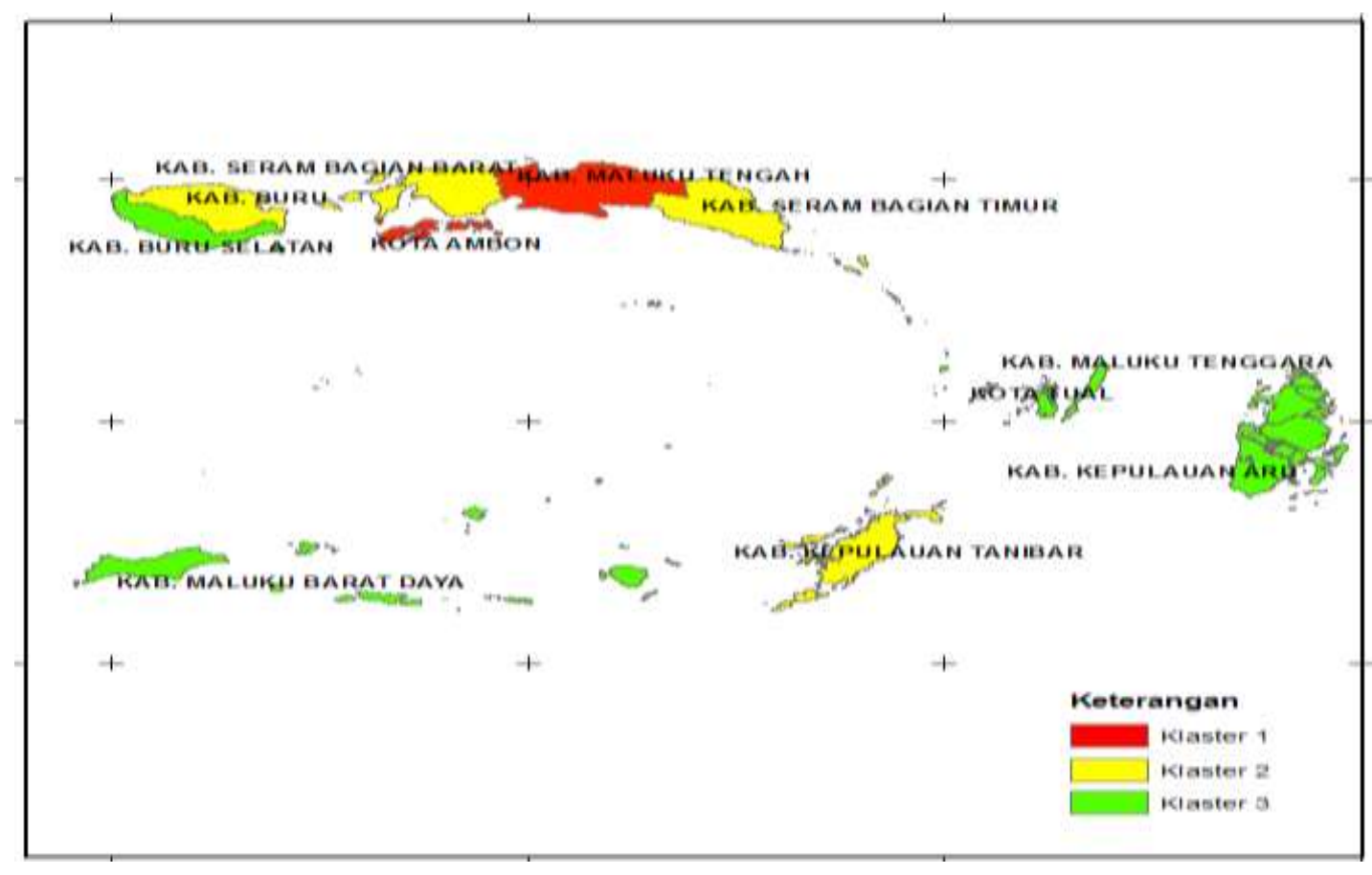

GAMBAR 1. Peta Ilustrasi Daerah Hasil Klaster dengan Metode Ward

Berdasarkan Gambar 1, diketahui bahwa klaster 1 nilai centroid tertinggi pada jumlah Siswa dan Guru sehingga klaster 1 dapat diberi nama klaster dengan tingkat pendidikan yang sangat baik. Klaster 2 mempunyai nilai centroid sedang pada jumlah Siswa dan Guru sehingga klaster 2 diberi nama klaster 
dengan tingkat pendidikan yang baik. Klaster 3 mempunyai nilai centroid terendah, maka klaster 3 diberi nama klaster dengan kondisi pendidikan dengan karakteristik wilayah yang minim. Untuk lebih jelasnya dapat dilihat pada Gambar 2, sebagai berikut:

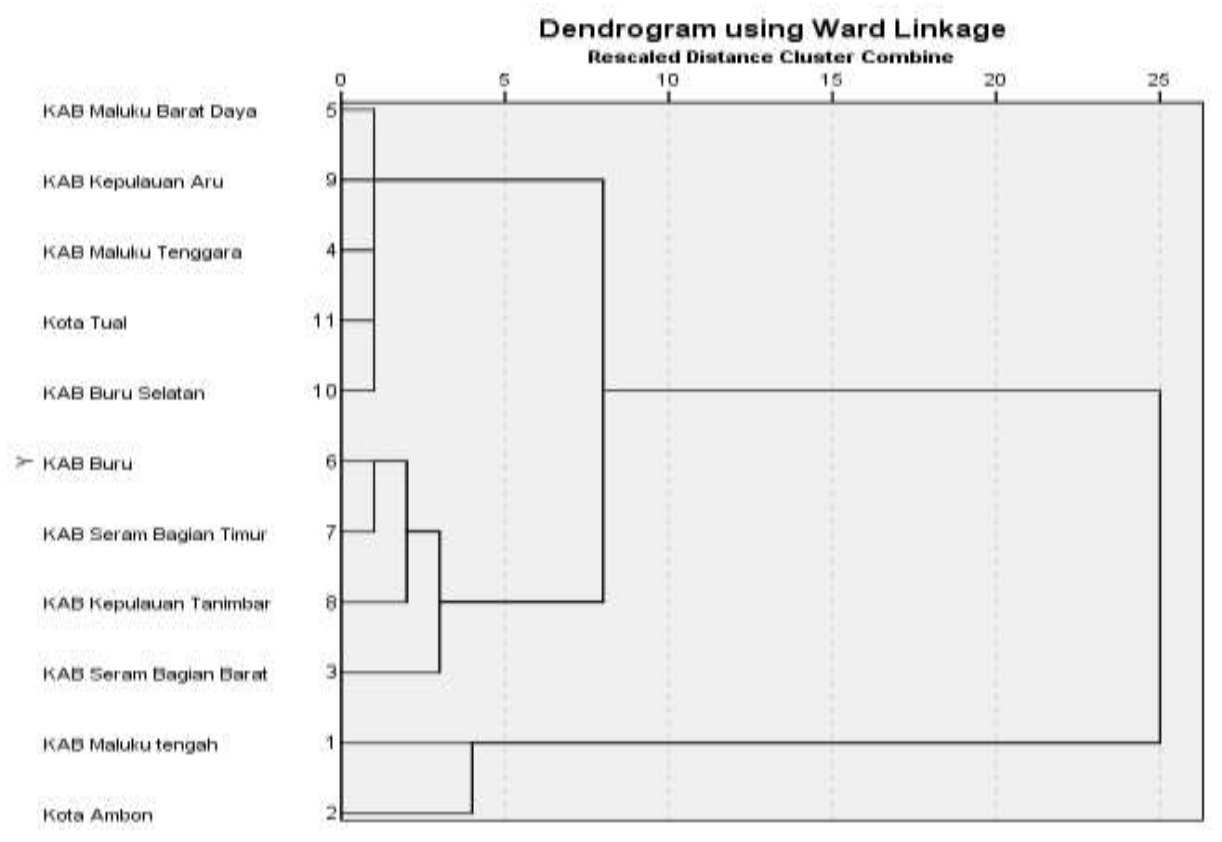

GAMBAR 2. Dendogram Analisis Klater dengan Menggunakan Metode Ward

Berdasarkan Gambar 2 diketahui bahwa pengklasteran Kabupaten/Kota di Provinsi Maluku menjadi klaster yang memiliki jumlah anggota yang berbeda pada masing-masing klaster yang telah terbentuk berdasarkan indikator pendidikan adalah sebagai berikut:

1. Klaster 1 yang beranggotakan Kabupaten Maluku Tengah dan Kota Ambon dengan tingkat pendidikan yang sangat baik.

2. Klaster 2 yang beranggotakan Kabupaten Seram Bagian Barat, Kabupaten Buru, Kabupaten Seram Bagian Timur dan Kabupaten Kepulauan Tanimbar dengan tingkat pendidikan yang rendah.

3. Klaster 3 yang beranggotakan Kabupaten Maluku Tenggara, Kabupaten Maluku Barat Daya, Kabupaten Kepulauan Aru, Kabupaten Buru Selatan dan Kota Tual dengan tingkat pendidikan yang minim.

\section{Melakukan Uji Validasi Klaster}

Untuk mengetahui apakah variabel-variabel yang telah membentuk klaster, digunakan kriteria dua nilai simpangan baku, yaitu rata-rata simpangan baku dalam klaster $(S w)$ dan simpangan baku antar klaster $(S b)$. Semakin kecil nilai rasio $(S w / S b)$ maka variabel tersebut memiliki kinerja yang baik, karena mempunyai tingkat homogenitas yang tinggi (Goreti et al, 2016).

1. Simpangan Baku Dalam Klaster $(S w)$

Simpangan baku klaster 1 dengan anggota 2 Kabupaten dan rata-rata variabel seluruh Kabupaten dimana nilai $\bar{X}_{1}=14111.083$.

$$
\begin{aligned}
S_{k} & =\sqrt{\frac{1}{n-1} \sum_{k=1}^{k}\left(x_{i}-x_{k}\right)} \\
S_{1} & =\sqrt{\frac{1}{2-1} \sum_{k=1}^{6}(71253-14111.083)+. .+(3695-14111.083)} \\
& =84666.502
\end{aligned}
$$


Simpangan baku klaster 2 dengan anggota 4 Kabupaten dan rata-rata variabel seluruh Kabupaten dimana nilai $\bar{X}_{2}=5501.16$

$$
\begin{aligned}
S_{2} & =\sqrt{\frac{1}{4-1} \sum_{k=1}^{24}(62850-5501.16)+\cdots+(2615-5501.16)} \\
& =29706.312
\end{aligned}
$$

Simpangan baku klaster 3 dengan anggota 5 Kabupaten dan rata-rata variabel seluruh Kabupaten dimana nilai $\bar{X}_{3}=3089.83$

$$
\begin{aligned}
S_{3} & =\sqrt{\frac{1}{5-1} \sum_{k=1}^{24}(7679-3089.83)+\cdots+(1901-3089.83)} \\
& =18539.005
\end{aligned}
$$

Jadi, nilai simpangan baku tiap klaster adalah

$$
\begin{aligned}
& S_{w 1}=25399.95 \\
& S_{w 2}=8911.89 \\
& S_{w 3}=5561.70
\end{aligned}
$$

2. Simpangan Baku Antar Klaster $(S b)$

$$
\begin{aligned}
S_{b} & =\left[\frac{1}{c-1} \sum_{k=1}^{c}\left(\bar{X}_{k}-\bar{X}\right)^{2}\right]^{\frac{1}{2}} \\
S_{b 1} & =247567296.3 \\
S_{b 2} & =128545540 \\
S_{b 3} & =44922118.55
\end{aligned}
$$

3. Rasio

$$
\begin{aligned}
& \mathrm{R}_{1}=\frac{s_{w}}{S_{b}}=0,0001 \\
& \mathrm{R}_{2}=\frac{S_{w}}{S_{b}}=0,00006 \\
& \mathrm{R}_{3}=\frac{S_{w}}{S_{b}}=0,0001
\end{aligned}
$$

Berdasarkan nilai rasio simpangan baku dalam tiap klaster dan simpangan baku antar klaster maka variabel tersebut memiliki kinerja yang baik, karena mempunyai tingkat homogenitas yang tinggi.

\section{KESIMPULAN DAN SARAN}

\section{Kesimpulan}

Berdasarkan analisis menggunakan metode Ward diperoleh hasil 3 klaster yaitu klaster pertama terdiri dari 2 kabupaten/kota yaitu Maluku Tengah dan Kota Ambon dengan tingkat pendidikan yang tinggi dalam pemerataan guru, klaster kedua terdiri dari 4 kabupaten yaitu Kabupaten Seram Bagian Barat, Kabupaten Buru, Kabupaten Seram Bagian Timur dan Kabupaten Kepulauan Tanimbar dengan tingkat pendidikan rendah, klaster ketiga terdiri dari 4 kabupaten/kota yaitu Kabupaten Maluku Tenggara, Kabupaten Maluku Barat Daya, Kabupaten Kepulauan Aru, Kabupaten Buru Selatan dan Kota Tual dengan tingkat pendidikan sedang.

\section{Saran}

Setelah diperoleh hasil peneliti hanya membahas tentang 1 metode dalam analisis klaster yaitu metode Ward. Sehingga kepada penelitian selanjutnya peneliti menyarankan adanya peningkatan penelitian yang lebih tentang indikator pendidikan dan lebih spesifik tentang analisis klaster khususnya metode hierarki dengan metode-metode yang lain. 


\section{REFERENSI}

Aprilia A. P, N. W. A., Srinadi, I. G. A. M., \& Sari, K. (2016). Pengelompokan Desa/Kelurahan Di Kota Denpasar Menurut Indikator Pendidikan. E-Jurnal Matematika, 5(2), 38. https://doi.org/10.24843/mtk.2016.v05.i02.p119.

Bertan, C. V. (2016, januari). pengaruh pendayagunaan sumber daya manusia (tenaga kerja) terhadap hasil pekerjaan (studi kasus perumahan taman mapancet raya (tamara)). Jurnal Sipil Statik, 4(1), 1320.

Fathia, A. N., Rahmawati, R., \& Tarno. (2016). Analisis Klaster Kecamatan Di Kabupaten Semarang Berdasarkan Potensi Desa Menggunakan Metode Ward Dan Single Linkage. Jurnal Gaussian, 5(4), 801-810.

Goreti, M., Novia, Y., \& Wahyuningsih, S. (2016). Perbandingan Hasil Analisis Cluster dengan Menggunakan Metode Single Linkage dan Metode C-Means. Jurnal EKSPONENSIAL, 7(1), 9-16.

Laome, L., Ngurah, G., Wibawa, A., Abapihi, B., Fitria, R., Statistika, P. S., Oleo, U. H., Program, A., Statistika, S. D., Vokasi, P. P., \& Oleo, U. H. (2019). Pengelompokkan desa berdasarkan indikator kesehatan dan peternakan dengan metode ward pada analisis gerombol berhierarki (studi kasus: kecamatan ranometo, kabupaten konsel, sulawesi tenggara). 191-197.

Oktarina, 2014. MetodeLinkage pada Persentase Kelahiran Balita Menurut Penolong Kelahirn Terakhir.Skripsi, Program Studi Matematika Fakultas Matematika dan Ilmu Pengetahuan Alam. Universitas Bengkulu.

Rahmawati, L. (2012). Analisis Kelompok Dengan Menggunakan Metode Hierarki Untuk Pengelompokan Kabupaten/Kota Di Jawa Timur Berdasar Indikator Kesehatan. Universitas Negeri sMalang. (Vol.1).

Selfianti, F., Lian, B., \& Wardarita, R. (2021). Pengaruh Kepemimpinan Kepala Sekolah dan Budaya Organisasi Terhadap Kinerja Guru SMP Se-Kecamatan Sako Palembang. Jurnal Pendidikan, 9(1).

Sela Oktavia, M. N. \& N. S. (2013). Pengelompokan Kinerja Dosen Jurusan Matematika Fmipa Untan Menggunakan Metode Ward. Buletin Ilmiah Mat. Stat. Dan Terapannya (Bimaster), 02(2), 93-100.

Silvi, R. (2018). Analisis Cluster dengan Data Outlier Menggunakan Centroid Linkage dan K-Means Clustering untuk Pengelompokkan Indikator HIV/AIDS di Indonesia. Jurnal Matematika "MANTIK," 4(1), 22-31. https://doi.org/10.15642/mantik.2018.4.1.22-31

Sumertajaya, I.M \& Erfiani. 2007. Analisis Gerombol Menggunakan Metode Two Step Cluster.Forum Statistika dan Komputasi, 12(1), 18-23

Wahidah Alwi \& Muh Hasrul. Analisis Cluster untuk Pengelompokkan Kabupaten/Kota di Propinsi Sulawesi Selatan Berdasarkan Indikator Kesejahteraan Rakyat. UINAM. 